Review

\title{
The Positive Effects of Yerba Maté (Ilex paraguariensis) in Obesity
}

\author{
Alessandra Gambero and Marcelo L. Ribeiro * \\ Laboratory of Microbiology and Molecular Biology, Clinical Pharmacology and Gastroenterology \\ Unit, Sao Francisco University Medical School, Av São Francisco de Assis 218, Bragança Paulista, \\ SP 12916-900, Brazil; E-Mail: alessandra.gambero@usf.edu.br
}

* Author to whom correspondence should be addressed; E-Mail: marcelo.ribeiro@usf.edu.br; Tel.: +55-11-2454-8982; Fax +55-11-4034-1825.

Received: 26 May 2014 / Accepted: 6 January 2015 / Published: 22 January 2015

\begin{abstract}
The prevalence of obesity has increased worldwide over the past three decades. Global anti-obesity strategies focus on dietary and lifestyle modifications to slow the development of obesity. Research in the nutrition field has recently aroused considerable interest based on the potential of natural products to counteract obesity. Several studies have identified yerba maté (Ilex paraguariensis) as an excellent candidate. In this review, we evaluated the impact of yerba maté on obesity and obesity-related inflammation. Cellular studies demonstrate that yerba maté suppresses adipocyte differentiation and triglyceride accumulation and reduces inflammation. Animal studies show that yerba maté modulates signaling pathways that regulate adipogenesis, antioxidant, anti-inflammatory and insulin signaling responses. In summary, the data presented here showed that the use of yerba maté might be useful against obesity, improving the lipid parameters in humans and animal models. In addition, yerba maté modulates the expression of genes that are changed in the obese state and restores them to more normal levels of expression. In doing so, it addresses several of the abnormal and disease-causing factors associated with obesity. Protective and ameliorative effects on insulin resistance were also observed. Thus, as a general conclusion, it seems that yerba maté beverages and supplements might be helpful in the battle against obesity.
\end{abstract}

Keywords: yerba maté; Ilex paraguariensis; obesity; adipogenesis; inflammation 


\section{Introduction}

The prevalence of obesity has increased worldwide. Obesity is a complex condition involving social, biological and psychosocial factors. A sedentary lifestyle and a high-calorie diet seem to be the most important factors in the development of obesity. Co-morbidities associated with obesity are serious and include several metabolic disorders, such as diabetes type 2 and atherosclerosis. Global anti-obesity strategies focus on dietary and lifestyle modifications to slow the development of obesity. Research in the nutrition field has recently aroused considerable interest based on the potential of natural products to counteract obesity. Several studies have identified yerba maté (Ilex paraguariensis A.St.-Hil) as an excellent candidate. In this review, we evaluated the in vitro and in vivo impact of yerba maté on obesity and obesity-related inflammation.

\section{Background on Obesity and Its Mechanisms}

The prevalence of obesity is a major public health concern, because of the associated weight-related diseases that result in significant morbidity and mortality and reduced quality of life. The energy balance defect that causes obesity and visceral adiposity is serious and predisposes individuals to complications, such as atherosclerosis, hepatic steatosis and type 2 diabetes [1]. The increasing incidence of obesity suggests that this epidemic will continue to grow [2]. A low-grade inflammatory process in adipose tissue has been identified as key in the development of obesity-associated pathologies, such as type 2 diabetes and cardiovascular diseases. In addition to adipose tissue's main role in releasing fatty acids to be used as energy substrates, this tissue is an active endocrine organ, secreting several hormones and signaling substances with a number of biological functions. Satiety and appetite control, glucose and lipid metabolism, blood pressure regulation and inflammation and immune modulation are altered by adipose tissue-derived substances.

Two important observations contributed to a change in the point of view regarding adipose tissue biology. The first was the discovery of leptin, an important hypothalamic satiety signal [3], in 1994 [4], and the subsequent data describing this hormone's proinflammatory actions [5]. The second was the description of adipocyte synthesis and the release of tumor necrosis factor (TNF)- $\alpha$, a classical proinflammatory substance [6].

The exact mechanism by which adipose tissue develops local inflammation during obesity is not fully understood. The mediators and mechanisms involved are complex and multifactorial. Adipose tissue contains not only adipocytes, but also adipocyte precursors, nerve terminals, blood vessels and immune cells, collectively named the stromal vascular fraction (SVF). In 2003, Weisberg described that approximately $40 \%$ of SVF cells from visceral adipose tissue in obese mice are macrophages compared to only $10 \%$ of SVF cells in lean controls [7]. In addition, infiltrated macrophages in adipose tissue from lean mice are different from those in adipose tissue from obese mice. Obesity induces not only macrophage infiltration, but also alterations in the macrophages’ phenotype. The M2:M1 macrophage ratio is reduced in adipose tissue of obese mice [8]. Human adipose tissue macrophages also present M1 characteristics [9]. M2 macrophages produce anti-inflammatory cytokines, such as interleukin (IL)-10, and have important functions in repair and remodelling, whereas M1 macrophages produce proinflammatory cytokines, such as TNF- $\alpha$ and IL-1 $\beta$, and have phagocytic and bactericidal functions [10]. 
Alterations in free fatty acid (FFA) concentrations could provide a chemotactic stimulus for macrophage infiltration through arachidonic acid products or the release of chemokines, such as monocyte chemoattractant protein-1 (MCP-1) [11,12]. Another hypothesis is that adipose tissue hypertrophy leads to hypoxia, resulting in local inflammation. Hypertrophied adipocytes can become as large as 150 to $200 \mu \mathrm{M}$ in diameter, and oxygen diffusion is impaired under this condition. Local hypoxia and upregulation of hypoxia-activated genes, like hypoxia-inducible factor-1 (HIF-1 $\alpha$ ) and vascular endothelial growth factor (VEGF), have been described in adipose tissue from mice and humans in obesity [13,14]. In addition, adipocytes are very sensitive to hypoxia and respond with an increase in proinflammatory mediator production [13,15]. Macrophage infiltration in response to lipotoxicity or hypoxia initiates recruitment of additional inflammatory cells, mainly through MCP-1 release, and results in elevated local production of proinflammatory cytokines, such as TNF- $\alpha$, IL-6 and IL-1 $\beta$, by these cells. These cytokines activate inflammatory pathways, resulting in activation of Jun $N$-terminal kinase-1 (JNK-1) and $\kappa B$ kinase (IKK $\beta$ ) inhibitor [16,17]. IKK $\beta$ disturbs insulin signaling through direct phosphorylation of insulin receptor substrate-1 (IRS-1) on serine residues or by phosphorylation of the nuclear factor- $\kappa \mathrm{B}(\mathrm{I} \kappa \mathrm{B})$ inhibitor, which dissociates nuclear factor- $\kappa \mathrm{B}(\mathrm{NF}-\kappa \mathrm{B})$, allowing this factor to translocate to the nucleus and activate inflammatory genes, such as TNF- $\alpha$, IL-6 and MCP-1 [16-18]. In addition, the JNK-1 signaling pathway also results in serine phosphorylation of IRS-1 and inflammatory gene transcription via transcription factor activator protein 1 (AP1) [19].

Inflammatory mediators produced in adipose tissue decrease the capacity of preadipocytes to differentiate. Defective adipogenesis is related to a decrease in the expression of differentiation-related genes, such as peroxisome proliferator-activated receptor- $\gamma 2$ (PPAR- $\gamma 2$ ) and transcription factor CCAAT/enhancer-binding protein (C/EBP)- $\alpha$ [20]. Thiazolidinediones (TZDs), which are known to activate PPAR- $\gamma$, are able to improve insulin signaling and glucose uptake by adipose tissue, despite also resulting in side effects, such as obesity [21].

Regarding adipogenesis, it involves a series of sequential events, such as cell cycle arrest, clonal expansion and differentiation. These events require several genes, the process probably begins with the activation of C/EBP- $\alpha, \mathrm{C} / \mathrm{EBP}-\beta$ and $\mathrm{C} / \mathrm{EBP}-\delta$ and is followed by PPAR $\gamma$ activation, which acts directly on different genes associated with adipogenesis [22-24]. Several studies have shown that PPAR $\gamma$ is a major regulator of adipogenesis and that the maintenance of its expression is essential for the progression through the late stages of differentiation [25]. PPAR 2 is primarily expressed in adipose tissue and promotes the differentiation and proliferation of adipocytes, which are derived from fibroblasts, resulting in an increase in adiposity [26]. Furthermore, the activation of PPAR $\gamma$ results in the expression of several pro-adipogenic genes, including C/EBP- $\alpha$ [27]. Therefore, it has been suggested that the self-regulation of C/EBP- $\alpha$ and PPAR $\gamma$ is critical for maintaining adipocyte differentiation [28,29].

\section{The Effects of Yerba Maté in Obesity}

Diet is an important regulatory factor of the inflammatory response and is directly responsible for obesity development in most obese subjects. Dietary bioactive compounds, such as polyphenols and certain fatty acids, are reported to suppress both systemic and adipose tissue inflammation and potentially improve these obesity-associated metabolic disorders [30]. 
Ilex paraguariensis (Aquifoliaceae), known commonly as yerba maté, is a plant originally from the subtropical region of South America, including southern Brazil, northern Argentina, Paraguay and Uruguay [31]. The aqueous extract of yerba maté is mainly prepared as four different beverages: chimarrão, maté cocido, tererê and maté tea. Both chimarrão and tererê are made with dried and crushed green maté leaves. The first is prepared with hot water, and the second is prepared with cold water. Maté tea is prepared with roasted leaves and brewed as any other herbal tea. Maté cocido refers to green maté brewed as an herbal tea, usually commercialized in bags sold as maté tea [32].

Maté beverages have been reported to have various biological activities, which have been attributed to the high polyphenol content of yerba maté. Phenolic compounds have long been known to possess biological functions. In addition to polyphenols, such as flavonoids (quercetin and rutin) and phenolic acids (chlorogenic and caffeic acids), yerba maté is also rich in caffeine and saponins [32]. Recently published research has scientifically proven that yerba maté has important pharmacological properties, such as antioxidant activity [33-38], protective effects against induced DNA damage [35], vasodilation activity [39], inhibition of glycation and atherosclerosis [31,40-42], improvement in glucose tolerance [42-44], anti-inflammatory effects [45-49], chemopreventive properties [50-53], thermogenic effects [49,54], amelioration of insulin resistance [42,45,55-57] and anti-obesity effects [44,46-49,54,56,58-63]. In addition, recently, Bracesco et al. [64] published a very informative and comprehensive review in which translational studies, inflammation and lipid metabolism were updated. Thereby, for further information about the issues that are not addressed in this review, it is recommended to read it.

The interest in yerba maté for health promotion is relatively recent. In the mid-90s, the first scientific evidence was published demonstrating the in vitro and in vivo antioxidant activity of yerba maté [33,65]. Likewise, antioxidant activity has been observed for many other natural products. Some researchers have also focused efforts on understanding the role of yerba maté in the modulation of obesity and obesity-associated conditions.

In 2001, the first study to evaluate the anti-obesity role of yerba maté was conducted. In this clinical study, the authors demonstrated that an herbal preparation containing yerba maté ("YGD”, yerba maté; guarana, Paullinia cupana Kunth; and damiana, Turnera diffusa Willd) significantly delayed gastric emptying, reducing the time to perceived gastric fullness, and induced significant weight loss over 45 days in overweight patients [66]. Subsequently, YGD has been demonstrated to produce a robust acute effect on caloric intake and meal duration, suggesting that YGD strengthens within-meal satiation, an effect that may be mediated by the previously reported changes in gastric emptying [67]. Moreover, in an elegant study, de Morais et al. [68] demonstrated the hypocholesterolemic effects of yerba maté in healthy subjects with normo- or dyslipidemia. The authors observed, after 20 and 40 days of treatment, a significantly reduction on the levels of low-density lipoprotein-cholesterol (LDL-C), non-high density lipoprotein cholesterol (non-HDL-C), apolipoprotein B (apo B), the LDL-C/HDL-C ratio and increasing HDL-C. In addition, it was demonstrated that yerba maté produced additional LDL-C lowering in hypercholesterolemic subjects who were on stable statin therapy, which may reduce the risk for cardiovascular diseases (Table 1). 
Table 1. In vivo effects of yerba maté on adipogenesis: human and animals studies.

\begin{tabular}{|c|c|c|c|c|c|}
\hline Study & Type of Study & Population & $\begin{array}{l}\text { Test Compounds } \\
\text { (Daily Dosage) }\end{array}$ & Duration of Intake & Main Outcomes \\
\hline $\begin{array}{c}\text { Andersen and Fogh, } \\
2001 \text { [66] }\end{array}$ & $\begin{array}{c}\text { Double-blind } \\
\text { placebo-controlled } \\
\text { parallel trial }\end{array}$ & $\begin{array}{l}\text { Forty-seven healthy overweight } \\
\text { (body mass index (BMI) range of } \\
25.8 \pm 30.4 \mathrm{~kg} / \mathrm{m}^{2} \text { ) volunteers. }\end{array}$ & $\begin{array}{l}\text { Three tablets of YGD } \\
\text { (112 mg yerba maté, } \\
95 \text { mg guarana and } \\
36 \text { mg damiana extract) } \\
\text { before each main meal. }\end{array}$ & $\begin{array}{l}10 \text { days and } 45 \text { days } \\
\text { and weight maintenance } \\
\text { over } 12 \text { months }\end{array}$ & $\begin{array}{l}\text { YGD significantly increased gastric emptying time } \\
\text { of } 58 \pm 15 \text { min compared to } 38 \pm 7.6 \text { min after } \\
\text { placebo; significantly increased body weight } \\
\text { reductions over } 10 \text { days ( } 0.8 \pm 0.05 \mathrm{~kg} \text { after YGD } \\
\text { compared with } 0.3 \pm 0.03 \mathrm{~kg} \text { after placebo) and } \\
\text { over } 45 \text { days ( } 5.1 \pm 0.5 \mathrm{~kg} \text { after YGD compared to } \\
0.3 \pm 0.08 \mathrm{~kg} \text { after placebo); treatment with YGD } \\
\text { resulted in weight maintenance ( } 73 \mathrm{~kg} \text { at the } \\
\text { beginning and } 72.5 \mathrm{~kg} \text { at the end of } 12 \text { months). }\end{array}$ \\
\hline $\begin{array}{c}\text { De Morais et al., } \\
2009 \text { [68] }\end{array}$ & $\begin{array}{l}\text { Single-blind } \\
\text { controlled trial }\end{array}$ & $\begin{array}{l}\text { One hundred and two volunteers } \\
\text { ( } n=36 \text { male and } 66 \text { female; } \\
\text { mean age }=48.4 \pm 1.35 \text { years). } \\
\text { Divided into } 3 \text { groups: } \\
\text { normolipidemic ( } n=15) \text {, } \\
\text { dyslipidemic ( } n=57) \text { and } \\
\text { hypercholesterolemic subjects on } \\
\text { long-term statin therapy }(n=30) \text {. }\end{array}$ & $\begin{array}{l}330 \mathrm{~mL}, 3 \text {-times/day } \\
\text { of green or roasted } \\
\text { yerba maté infusions. }\end{array}$ & 40 days & $\begin{array}{l}\text { Normolipidemic subject treated with yerba maté } \\
\text { exhibited a significative reduction of } 8.7 \% \text { on } \\
\text { LDL-cholesterol. Dyslipidemic individuals lowered } \\
\text { LDL-cholesterol levels up to } 8.6 \% \text { and non-HDL } \\
\text { cholesterol up to } 6.5 \% \text {. The apolipoprotein B level } \\
\text { was reduced by } 6.0 \% \text {, and HDL-cholesterol was } \\
\text { significantly increased by } 4.4 \% \text {. The yerba maté } \\
\text { consumption by hypercholesterolemic individuals } \\
\text { on statin therapy promoted an additional } 13.1 \% \\
\text { reduction in LDL-C and increased HDL cholesterol } \\
\text { by } 6.2 \% \text {. }\end{array}$ \\
\hline
\end{tabular}


Table 1. Cont

\begin{tabular}{|c|c|c|c|c|c|}
\hline Study & Type of Study & Population & Test Compounds (Daily Dosage) & Duration of Intake & Main Outcomes \\
\hline $\begin{array}{c}\text { Harrold et al., } \\
2013 \text { [67] }\end{array}$ & $\begin{array}{l}\text { Double blind, } \\
\text { placebo-controlled, } \\
\text { crossover }\end{array}$ & $\begin{array}{l}\text { Fifty-eight healthy women, } \\
\text { aged 18-65, with a BMI } \\
\text { between } 18.5 \text { and } 29.9 \mathrm{~kg} / \mathrm{m}^{2} \text {. }\end{array}$ & $\begin{array}{c}\text { Three tablets of YGD } \\
\text { (112 mg yerba maté, } 95 \text { mg guarana and } \\
36 \text { mg damiana extract) and inulin-based soluble } \\
\text { fermentable fiber (SSF; } 5 \text { g in } 100 \mathrm{~mL} \text { water), } \\
3 \text { tablets of YGD and water (100 mL), SFF and } \\
\text { placebo (3 tablets) or water and placebo } 15 \text { min } \\
\text { before lunch. }\end{array}$ & 1 day & $\begin{array}{l}\text { YGD and SFF significantly reduced food and } \\
\text { energy intake ( } 59.5 \mathrm{~g}, 16.3 \% \text {; } 112.4 \mathrm{kcal}, 17.3 \% \text {; } \\
\text { and } 31.9 \mathrm{~g}, 9.1 \% \text {; } 80 \mathrm{kcal}, 11.7 \% \text {, respectively) } \\
\text { compared with conditions where they were } \\
\text { absent. The lowest intake (gram and kcal) was } \\
\text { observed in the YGD + SFF combination. } \\
\text { In summary, YGD causes a robust short-term } \\
\text { effect on caloric intake, an effect augmented } \\
\text { by SFF. }\end{array}$ \\
\hline $\begin{array}{c}\text { Pang et al., } \\
2008[58]\end{array}$ & Experimental & $\begin{array}{l}\text { Sprague-Dawley rats fed } \\
\text { with high-fat diet (3 groups, } \\
\qquad n=8 \text { each). }\end{array}$ & $\begin{array}{l}\text { High-fat diet (HFD) supplemented with maté } \\
\qquad \text { (ad libitum). }\end{array}$ & 8 weeks & $\begin{array}{l}\text { Yerba maté extract significantly reduced } \\
\text { the final body weight. It reversed the } \\
\text { HFD-induced downregulation of the adipose } \\
\text { tissue genes implicated in adipogenesis } \\
\text { or thermogenesis. Significant decreases } \\
\text { in the phospho-AMP-activated protein } \\
\text { kinase (AMPK)/AMPK protein ratio were } \\
\text { also observed. }\end{array}$ \\
\hline $\begin{array}{c}\text { Arçari et al., } \\
2009 \text { [49] }\end{array}$ & Experimental & $\begin{array}{l}\text { Swiss mice fed with high-fat } \\
\text { diet ( } 3 \text { groups, } n=10 \text { each). }\end{array}$ & $\begin{array}{c}1 \mathrm{~g} / \mathrm{kg} \text { of roasted yerba maté extract by oral } \\
\text { route (once per day). }\end{array}$ & 8 weeks & $\begin{array}{l}\text { Yerba maté significantly inhibited the } \\
\text { inflammation in adipose tissue induced by } \\
\text { obesity, modulating several pro- and } \\
\text { anti-inflammatory genes and reducing } \\
\text { macrophage infiltration. }\end{array}$ \\
\hline
\end{tabular}


Table 1. Cont

\begin{tabular}{|c|c|c|c|c|c|}
\hline Study & Type of Study & Population & Test Compounds (Daily Dosage) & Duration of Intake & Main Outcomes \\
\hline $\begin{array}{c}\text { Martins et al., } \\
2010 \text { [63] }\end{array}$ & Experimental & $\begin{array}{l}\text { Swiss mice fed with high-fat diet } \\
\text { (4 groups, } n=10 \text { each). }\end{array}$ & $\begin{array}{l}1 \text { and } 2 \text { g/kg of roasted yerba maté } \\
\text { extract by oral route (once per day). }\end{array}$ & 8 weeks & $\begin{array}{l}\text { Yerba maté extract significantly reduced the final } \\
\text { body weight. A reduction of total serum cholesterol } \\
\text { and LDL-cholesterol levels was observed. Serum } \\
\text { triglycerides were also significantly reduced. } \\
\text { Yerba maté significantly reduced lipid accumulation } \\
\text { in the liver (decreased by } \sim 30 \%) \text {. }\end{array}$ \\
\hline $\begin{array}{l}\text { Arçari et al., } \\
2011 \text { [45] }\end{array}$ & Experimental & $\begin{array}{l}\text { Swiss mice fed with high-fat diet } \\
\text { (3 groups, } n=10 \text { each). }\end{array}$ & $\begin{array}{c}1 \mathrm{~g} / \mathrm{kg} \text { of roasted yerba maté extract } \\
\text { by oral route (once per day). }\end{array}$ & 8 weeks & $\begin{array}{l}\text { Yerba maté significantly improved insulin resistance } \\
\text { by restoring hepatic and muscle IRS-1 and AKT } \\
\text { phosphorylation and by controlling adipose tissue } \\
\text { inflammation associated with obesity. }\end{array}$ \\
\hline $\begin{array}{c}\text { Hussein et al., } \\
2011[43]\end{array}$ & Experimental & $\begin{array}{l}\text { Male Tsumura Suzuki obese } \\
\text { diabetic (TSOD) mice } \\
\text { (3 groups, } n=5 \text { each). }\end{array}$ & $\begin{array}{c}100 \mathrm{mg} / \mathrm{kg} \text { of an aqueous extract of } \\
\text { yerba maté by oral route (once per day). }\end{array}$ & 7 weeks & $\begin{array}{l}\text { Significantly ameliorated metabolic syndrome by } \\
\text { improving peripheral insulin sensitivity and cellular } \\
\text { glucose uptake and by modulating the level of } \\
\text { circulating lipid metabolites and adiponectin. }\end{array}$ \\
\hline $\begin{array}{c}\text { Hussein et al., } \\
2011[61]\end{array}$ & Experimental & DdY mice fed with high-fat diet. & $\begin{array}{l}\text { Aqueous extract of maté by oral route } \\
\text { (once per day). }\end{array}$ & 3 weeks & $\begin{array}{l}\text { Administration of yerba maté induced significant } \\
\text { increases in GLP-1 levels and leptin levels, generating } \\
\text { anorexic effects by direct induction of satiety. }\end{array}$ \\
\hline $\begin{array}{c}\text { Kang et al., } \\
2012 \text { [44] }\end{array}$ & Experimental & $\begin{array}{l}\text { C57BL/6J mice fed with high-fat } \\
\text { diet (5 groups, } n=5 \text { each). }\end{array}$ & $\begin{array}{l}0.5,1 \text { or } 2 \mathrm{~g} / \mathrm{kg} \text { of aqueous extract of } \\
\text { yerba maté by oral route } \\
\text { (once per day). }\end{array}$ & 4 weeks & $\begin{array}{l}\text { Yerba maté consumption significantly reduced the } \\
\text { body weight, adiposity, adipocyte size and leptin } \\
\text { release by adipose tissue. Maté-treated mice also } \\
\text { presented a significant reduction in serum levels } \\
\text { of triglycerides and cholesterol. }\end{array}$ \\
\hline
\end{tabular}


Table 1. Cont

\begin{tabular}{|c|c|c|c|c|c|}
\hline Study & Type of Study & Population & Test Compounds (Daily Dosage) & Duration of Intake & Main Outcomes \\
\hline $\begin{array}{c}\text { Pimentel et al., } \\
2012[46]\end{array}$ & Experimental & $\begin{array}{l}\text { Wistar rats fed with high-fat diet } \\
\text { (3 groups, } n=7 \text { each). }\end{array}$ & $\begin{array}{c}\text { From } 100 \text { to } 200 \mathrm{mg} / \mathrm{kg} \text { of } \\
\text { yerba maté extract by oral route } \\
\text { (once per day). }\end{array}$ & 8 weeks & 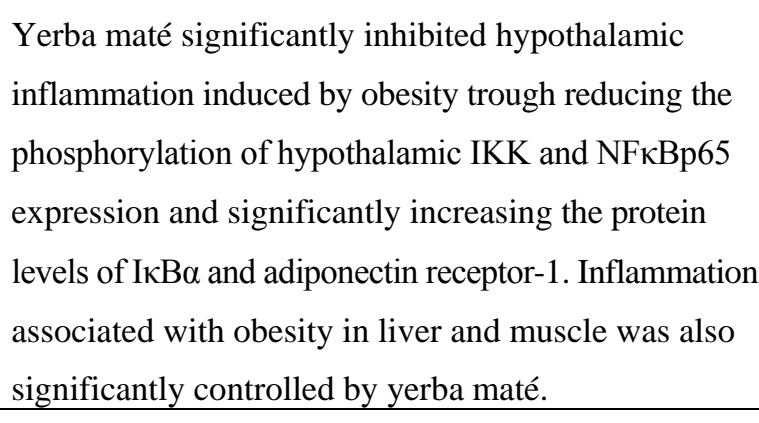 \\
\hline $\begin{array}{c}\text { Arçari et al., } \\
2013 \text { [57] }\end{array}$ & Experimental & $\begin{array}{l}\text { Swiss mice fed with high-fat diet } \\
\text { (3 groups, } n=10 \text { each). }\end{array}$ & $\begin{array}{c}1 \mathrm{~g} / \mathrm{kg} \text { of roasted yerba maté extract } \\
\text { by oral route (once per day). }\end{array}$ & 8 weeks & $\begin{array}{l}\text { Significantly improved insulin resistance by } \\
\text { restoring hepatic FOXO1 nuclear translocation } \\
\text { and upregulating gene expression of Akt2, Irs1, } \\
\text { Irs2, Pi3kca, Pi3kcg and Pdk1. }\end{array}$ \\
\hline $\begin{array}{c}\text { Arçari et al., } \\
2013 \text { [59] }\end{array}$ & Experimental & $\begin{array}{l}\text { Swiss mice fed with high-fat diet } \\
\text { (3 groups, } n=10 \text { each). }\end{array}$ & $\begin{array}{c}1 \mathrm{~g} / \mathrm{kg} \text { of roasted yerba maté extract } \\
\text { by oral route (once per day). }\end{array}$ & 8 weeks & $\begin{array}{l}\text { Yerba maté extract significantly reduced the final } \\
\text { body weight. It downregulated the expression of } \\
\text { genes that regulate adipogenesis and upregulated } \\
\text { the expression of genes related to the inhibition } \\
\text { of adipogenesis. }\end{array}$ \\
\hline $\begin{array}{c}\text { Borges et al., } \\
2013 \text { [48] }\end{array}$ & Experimental & $\begin{array}{l}\text { Wistar rats fed a with high-fat diet } \\
\text { (4 groups, } n=8-12 \text { each). }\end{array}$ & $\begin{array}{c}1 \mathrm{~g} / \mathrm{kg} \text { of roasted yerba maté extract } \\
\text { by oral route } \\
\text { (once per day). }\end{array}$ & 4 weeks & $\begin{array}{l}\text { The consumption of yerba maté promoted weight } \\
\text { loss, attenuated the detrimental effects of HFD on } \\
\text { adiposity and insulin sensitivity and decreased the } \\
\text { blood levels of inflammatory biomarkers. Concerning } \\
\text { peritoneal macrophages, maté decreased the mRNA } \\
\text { production of } I l-6 \text {, but did not influence the } \\
\text { production of } I l-1 \beta \text {, Tnf- } \alpha \text { and nitric oxide. }\end{array}$ \\
\hline
\end{tabular}


Table 1. Cont.

\begin{tabular}{|c|c|c|c|c|c|}
\hline Study & Type of Study & Population & $\begin{array}{l}\text { Test Compounds } \\
\text { (Daily Dosage) }\end{array}$ & Duration of Intake & Main Outcomes \\
\hline $\begin{array}{l}\text { Carmo et al., } \\
2013 \text { [47] }\end{array}$ & Experimental & $\begin{array}{l}\text { Wistar rats fed a with high-fat diet } \\
\text { (4 groups, } n=8-12 \text { each). }\end{array}$ & $\begin{array}{c}1 \mathrm{~g} / \mathrm{kg} \text { of roasted yerba maté } \\
\text { extract by oral route } \\
\text { (once per day) }\end{array}$ & 4 weeks & $\begin{array}{l}\text { Significantly reduced body weight, body adiposity and } \\
\text { cholesterol levels. Maté consumption reduced IL-1 } \alpha \text {, } \\
\text { IL-6 and TNF- } \alpha \text { production by bone marrow cells. }\end{array}$ \\
\hline $\begin{array}{l}\text { Gao et al., } \\
2013 \text { [69] }\end{array}$ & Experimental & $\begin{array}{l}\text { Sprague-Dawley rats fed with high-fat } \\
\text { diet (5 groups, } n=12 \text { each). }\end{array}$ & $\begin{array}{c}12 \text { and } 4 \% \text { yerba maté extract. } \\
\text { The animals had free access to } \\
\text { bottles containing the prepared } \\
\text { infusion as the only available } \\
\text { liquid source. }\end{array}$ & 4 weeks & $\begin{array}{l}\text { Yerba maté may regulate blood lipid and endothelial } \\
\text { function in hyperlipidemia rats. The putative mechanism } \\
\text { may include a reduction of endothelin and thromboxane } \mathrm{A}_{2} \\
\text { levels and an increase in nitric oxide and 6-keto-PGF1 } \alpha \\
\text { levels in the blood, downregulating the expression of } \\
\text { ICAM-1 (Intercellular Adhesion Molecule 1) protein and } \\
\text { upregulating the expression of LDLR (LDL receptor) and } \\
\text { SR-B1 (scavenger receptor class B member 1) genes, } \\
\text { inhibiting the occurrence of atherosclerosis. }\end{array}$ \\
\hline $\begin{array}{c}\text { Lima et al., } \\
2014[56]\end{array}$ & Experimental & Wistar rats primed by early weaning. & $\begin{array}{l}1 \mathrm{~g} / \mathrm{kg} \text { of yerba maté extract by } \\
\text { oral route (once per day). }\end{array}$ & 4 weeks & $\begin{array}{l}\text { Yerba maté consumption significantly reduces body } \\
\text { weight, adiposity and triglycerides levels in the blood. }\end{array}$ \\
\hline
\end{tabular}


In addition to human studies, in DdY mice fed with high-fat diet animal models, yerba maté has been suggested to promote satiety through various mechanisms, including induction and/or enhancement of intestinal glucagon-like peptide-1 (GLP-1), modulation of serum leptin levels and a possible direct central satiety-stimulatory effect [61]. Data obtained from experiments conducted in diet-induced obesity models have shown that yerba maté suppresses body weight gain and visceral fat accumulation and decreases serum levels of cholesterol, triglycerides, LDL cholesterol, glucose, insulin, pancreatic lipase and leptin [39,44,47-49,56,58,59]. Additionally, yerba maté reduces endothelin and thromboxane $\mathrm{A}_{2}$ levels and increases nitric oxide and 6-keto-PGF1 $\alpha$ levels in the blood, inhibiting the occurrence of atherosclerosis [69]. It has been suggested that the high polyphenol content of yerba maté might be responsible for these observed results. In this sense, chlorogenic acid, the main polyphenol in yerba maté, is thought to modulate the activity of glucose-6-phosphatase, which is involved in glucose metabolism [70], and to reduce the risk of cardiovascular disease by decreasing LDL and cholesterol oxidation [71]. Additionally, it has been suggested that the hypolipidemic effects of yerba maté could be attributed, at least in part, to its saponin content [72] (Table 1).

The molecular mechanisms by which yerba maté regulates obesity have also been studied. In this regard, several studies have been conducted in cellular models and in obese animals to evaluate the effects of yerba maté on several genes related to adipogenesis. Adipogenesis is the developmental process by which a multipotent mesenchymal stem cell differentiates into a mature adipocyte. This process involves a highly regulated and coordinated cascade of transcription factors, including members of the PPAR, C/EBP and sterol regulatory element-binding protein (SREBP) families, which together lead to the establishment of the differentiated state [21]. In this context, it has been observed that yerba maté modulates adipogenesis by regulating the gene expression levels of pro-adipogenic transcription factors, such as Ppar- $\gamma 2$ [49,58,59] and C/ebp- $\alpha$ [59], in vivo and in vitro [59,60]. C/EBP and Ppar- $\gamma 2$ expression depends on other genes that are also essential to adipogenesis, such as cAMP responsive element binding protein 1 (Creb1) and delta-like 1 homolog (Drosophila) (Dlk1); Arcari et al. [59] showed that yerba maté modulates the in vivo and in vitro expression of these genes, thus contributing directly to adipogenesis regulation (Figure 1, Tables 1 and 2).

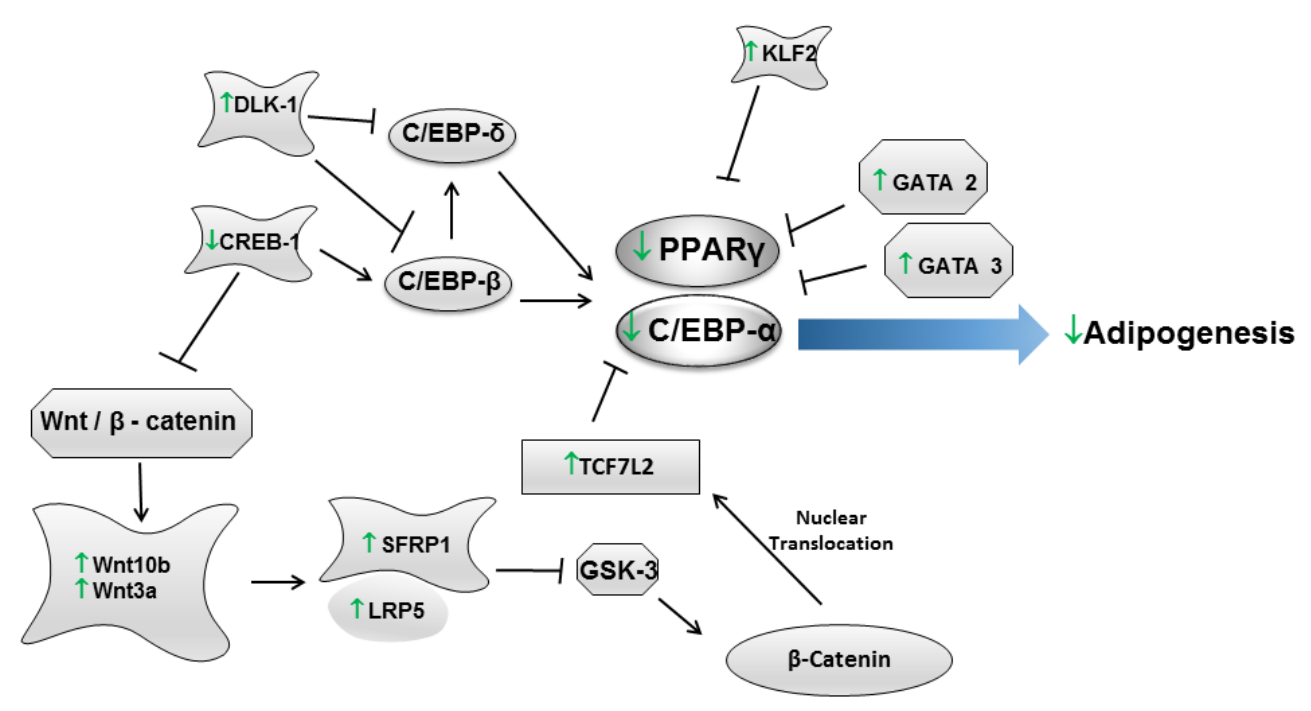

Figure 1. In vivo and in vitro effects of yerba maté in adipogenesis. 
In addition, it has been shown that yerba maté regulates adipogenesis in a $\beta$-catenin-dependent manner [59]. The $\beta$-catenin-dependent signaling pathway is initiated by the binding of the wingless-type MMTV integration site family (WNT) 1, WNT3a and WNT10b to secreted frizzled-related protein (SFRP) 1 and SFRP5 and low density lipoprotein receptor-related protein (LRP) 5 and LRP6 receptors. The expression of WNT10b stabilizes $\beta$-catenin in the cytoplasm, thereby inhibiting adipogenesis. Data indicate that among the WNT proteins, WNT10b is the primary adipogenesis regulator, and WNT1 and WNT3a act synergistically [73]. The binding of WNT to its receptors (SFRP and LRP) inhibits glycogen synthase kinase (GSK)-3, resulting in the hypophosphorylation of $\beta$-catenin. $\beta$-Catenin translocates to the nucleus, where it binds to a TCF/LEF transcription factor, repressing the expression of $\mathrm{C} / \mathrm{EBP} \alpha$ and PPAR $\gamma$ and, therefore, inhibiting adipogenesis [24]. Arcari et al. [59] demonstrated that yerba maté modulates adipogenesis in vitro and in vivo via the WNT pathway by increasing the mRNA levels of Wnt10B, Wnt3A, Sfrp1 and Lrp5, which favor the nuclear translocation of $\beta$-catenin, thereby increasing the expression of Tcf7l2. An increase in Tcf7l2 (transcription factor 7-like 2 (T-cell specific, HMG-box)) could lead to the repression of C/ebp $\alpha$ and Ppar- $\gamma 2$, thereby reducing adipogenesis. In addition, it has been shown that the GATA and Krüppel-like zinc finger (KLF) proteins also directly affect adipogenesis. It has been suggested that increased expression of GATA-2 and GATA-3 suppresses adipocyte differentiation through a direct repression of C/EBP- $\alpha$ and PPAR $\gamma$ [74]. Regarding KLF, it has been demonstrated that KLF2 inhibits adipogenesis by inhibiting PPAR $\gamma$ [75]. Arcari et al. [59] observed that yerba maté enhanced the gene expression of Gata2, Gata3 and Klf2, which may contribute to the inhibition of adipogenesis via the PPAR $\gamma$ pathway (Figure 1, Tables 1 and 2). Taking into account that yerba maté is rich in several bioactive compounds, it has been attempted to assess whether any of these compounds would have a greater effect in the inhibition of adipogenesis [59,60]. The results from these showed that synergism between these compounds might be responsible for the results observed in the yerba maté intervention group. 
Table 2. In vitro effects of yerba maté on adipogenesis.

\begin{tabular}{|c|c|c|c|c|}
\hline Study & Type of Cell (Origin) & Assay Employed & Tested Compounds (Concentration) & Main Outcomes \\
\hline $\begin{array}{c}\text { Martins et al., } \\
2010 \text { [63] }\end{array}$ & None * & $\begin{array}{l}\text { Determination of lipase activity } \\
\text { inhibitory action against porcine and } \\
\text { human lipases and the influence of } \\
\text { several olive oil emulsifying reagents. }\end{array}$ & $0.5-5.0 \mathrm{mg} / \mathrm{mL}$ of roasted yerba maté. & $\begin{array}{l}\text { Yerba maté significantly inhibited the enzyme activities } \\
\text { in a dose-dependent way, and its inhibitory activity } \\
\text { against both lipases reached a maximum at } 3.0 \mathrm{mg} / \mathrm{mL} \text {, } \\
\text { corresponding to } 9 \mathrm{mg} \text { of tea/g substrate. Kinetic results } \\
\text { indicated that yerba maté competitively inhibited } \\
\text { pancreatic lipase activity in a concentration-dependent } \\
\text { manner with a half-maximal inhibitory concentration } \\
\text { value of } 1.5 \mathrm{mg} \text { yerba maté/mL (or } 4.5 \mathrm{mg} \text { of } \\
\text { yerba maté/g of substrate), whereas a drastic decrease } \\
\text { in lipolytic activity (> } 80 \% \text { that of the control) was } \\
\text { observed in the presence of } 3.0 \mathrm{mg} \text { yerba maté/mL. }\end{array}$ \\
\hline $\begin{array}{l}\text { Gosmann et al., } \\
2012 \text { [60] }\end{array}$ & 3T3-L1 (Mus musculus) & $\begin{array}{l}\text { Determination of phenolic compounds } \\
\text { (Folin-Ciocalteu method), Oil Red O } \\
\text { staining and gene expression. }\end{array}$ & $\begin{array}{l}\text { Extracts of both fresh and dried maté } \\
\text { leaves subjected to chromatography in } \\
\text { order to obtain the saponin ( } 20 \% \text { yield) } \\
\text { and the polyphenol extracts ( } 40 \% \text { yield). }\end{array}$ & $\begin{array}{l}\text { Among the yerba maté samples, the polyphenol extract } \\
\text { of fresh leaves exhibited a higher content of total } \\
\text { phenols, followed by the polyphenol extract and the } \\
\text { ethanol extract of dried leaves. Saponin extracts of both } \\
\text { fresh and dried leaves exhibited lower contents of } \\
\text { phenolic compounds. Regarding adipogenesis, the } \\
\text { highest anti-adipogenic effect was detected in the } \\
\text { polyphenol extract of dried leaves at } 50 \mu \mathrm{g} / \mathrm{mL} \text {, } \\
\text { followed by the saponin extract of fresh leaves at } \\
100 \mu \mathrm{g} / \mathrm{mL} \text { and by the polyphenol extract of fresh } \\
\text { leaves at } 500 \mu \mathrm{g} / \mathrm{mL} \text {. All assayed samples restrained } \\
\text { the expression of the PPAR } 2, L e p, T N F-\alpha \text { and } \\
C / E B P \alpha \text { genes. }\end{array}$ \\
\hline
\end{tabular}


Table 2. Cont.

\begin{tabular}{|c|c|c|c|c|}
\hline Study & Type of Cell (Origin) & Assay Employed & $\begin{array}{c}\text { Tested Compounds } \\
\text { (Concentration) }\end{array}$ & Main Outcomes \\
\hline $\begin{array}{c}\text { Arcari et al., } \\
2013 \text { [59] }\end{array}$ & 3T3-L1 (Mus musculus) & $\begin{array}{l}\text { Oil Red O staining and gene } \\
\text { expression (Mouse Adipogenesis } \\
\text { RT }^{2} \text { Profiler }{ }^{\mathrm{TM}} \text { PCR Array). }\end{array}$ & $\begin{array}{l}\text { 50, } 250 \text { or } 500 \mu \mathrm{g} / \mathrm{mL} \text { of } \\
\text { roasted yerba maté, } \\
\text { chlorogenic acid, quercetin, } \\
\text { and rutin (Sigma-Aldrich). }\end{array}$ & $\begin{array}{l}\text { Yerba maté extract and chlorogenic acid inhibited adipogenesis at } \\
\text { a concentration of } 50 \mu \mathrm{g} / \mathrm{mL} \text {. Quercetin and rutin had inhibitory } \\
\text { activity at the highest concentration. The PCR array revealed that } \\
\text { yerba maté modulated the expression of } 14 \text { genes (belonging to } \\
\text { PPAR } \gamma \text { and WNT signaling pathways) that are associated with } \\
\text { adipogenesis. In addition, the bioactive compounds also modulated } \\
\text { the expression of adipogenesis-associated genes. However, fewer } \\
\text { genes were regulated by chlorogenic acid, quercetin and rutin than } \\
\text { by yerba maté. The authors claim that the synergism between } \\
\text { these compounds might be responsible for the results observed. }\end{array}$ \\
\hline
\end{tabular}

* Pancreatic lipase activity was based on the amount of free fatty acids liberated from emulsified olive oil (using human and porcine lipases that were commercially available). 
Furthermore, besides the effects on adipogenesis regulators, yerba maté has been demonstrated to act on the expression of genes related to thermogenesis. Pang et al. [58] demonstrated that yerba maté can have a protective effect against obesity in a rodent model through enhanced uncoupled respiration via uncoupling protein (UCP) 2 and UCP 3 expression. Arcari et al. [49] also showed that yerba maté modulates thermogenesis by increasing the mRNA levels of Pgcl $\alpha$ (peroxisome proliferator-activated receptor gamma, coactivator 1 alpha) and UCP 1 in brown adipose tissue.

As mentioned before, obesity is associated with a state of chronic, low-grade inflammation characterized by abnormal cytokine production and the activation of inflammatory signaling pathways in adipose tissue [76]. Thus, the anti-inflammatory role of yerba maté has also been targeted. In adipose tissue, it has been shown that yerba maté has potent anti-inflammatory effects, downregulating the expression of Tnf- $\alpha$, Il-6, Lep (leptin), Pai1 (plasminogen activator inhibitor type), Ccl2 (chemokine (C-C motif) ligand2) and Ccr2 (chemokine (C-C motif) receptor 2) and upregulating AdipoR1 (adiponectin receptor 1) [49]. In liver, yerba maté was found to reduce the nuclear translocation of NF- $\kappa B$, which downregulates the mRNA levels of Il-6, Nos2 (nitric oxide synthase 2) and Tnf- $\alpha$ [45]. Subsequently, it was observed that yerba maté reversed hypothalamic inflammation caused by high-fat

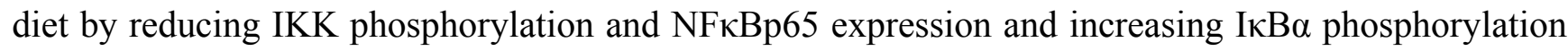
and the expression of Adipor1 and IRS-2 in the hypothalamus [46]. On the other hand, it was reported that yerba maté consumption did not affect the NF- $\kappa$ B signaling pathway in peritoneal macrophages; however, yerba maté consumption improved systemic markers of inflammation, such as IL-6, PAI1 and TNF- $\alpha$ [48].

It is well known that an increase in adipokine production can influence glucose metabolism, insulin sensitivity and inflammation, and this finding could represent a molecular link between obesity and the development of diabetes mellitus, metabolic syndromes and cardiovascular diseases [77]. The effects of yerba maté extract on insulin resistance and gene expression of inflammatory markers have been studied in animal models. Several studies indicate that yerba maté improves glucose tolerance in obese animals [43,45,48,57], along with an increase in the constant of insulin tolerance test (KITT) value [45,57]. In addition, yerba maté inhibited hepatic Tnf- $\alpha$ and restored hepatic and muscle insulin signaling through an increase in IRS-1 tyrosine phosphorylation in mice with high fat diet-induced obesity [45]. Because one of the earliest steps in the insulin signaling pathway is phosphatidylinositol 3-kinase (PI3K) activation [78], the effects of yerba maté on this pathway have also been reported. Arcari et al. [57] demonstrated that yerba maté has a modulatory effect on different insulin-related target genes (Akt2, Irs1, Irs2, Pi3kca, Pi3kcg and Pdk1 (pyruvate dehydrogenase kinase, isoenzyme 1)) in the liver of animals subjected to a high-fat diet. Furthermore, yerba maté downregulates phosphoenolpyruvate carboxykinase 1, cytosolic (Pepck) and glucose-6-phosphatase, catalytic (G6pc), the main gluconeogenesis genes, through a decrease in forkhead box O (FOXO) 1 nuclear translocation (Figure 2). 


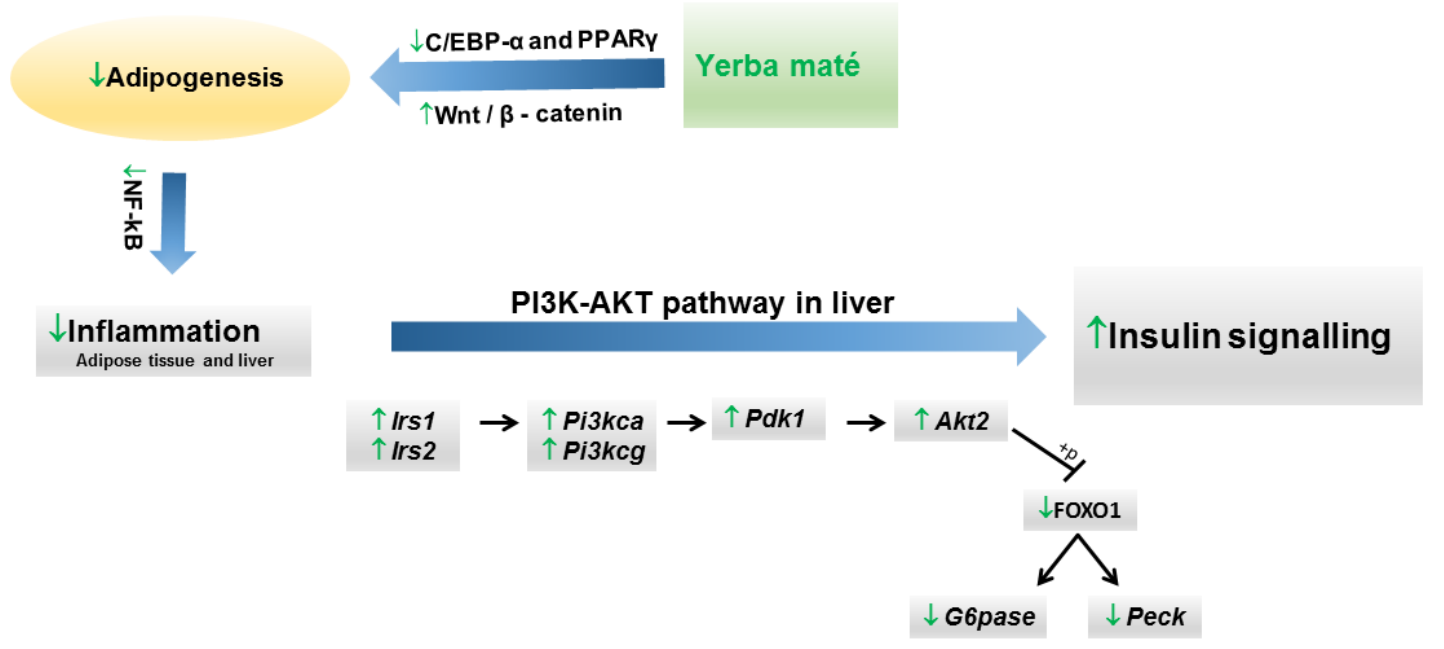

Figure 2. Proposed mechanism of action of yerba maté on the modulation of the PI3K-AKT signaling pathway.

\section{Conclusions}

In summary, the data presented here showed that the use of yerba maté might be useful against obesity, improving the lipid parameters in humans and animal models. In addition, yerba maté modulates the expression of genes that are changed in the obese state and restores them to more normal levels of expression. In doing so, it addresses several of the abnormal and disease-causing factors associated with obesity. Protective and ameliorative effects on insulin resistance were also observed. Thus, as a general conclusion, it seems that yerba maté beverages and supplements might be helpful in the battle against obesity.

\section{Author Contributions}

Alessandra Gambero contributed to the review of the literature and the preparation of the manuscript section "Background on Obesity and Its Mechanisms"; Marcelo L. Ribeiro contributed to the review of the literature and the preparation of the manuscript section "Effects of Yerba Maté in Obesity".

\section{Conflicts of Interest}

The authors declare no conflict of interest.

\section{References}

1. Berg, A.H.; Scherer, P.E. Adipose tissue, inflammation, and cardiovascular disease. Circ. Res. 2005, 96, 939-949.

2. Haslam, D.W.; James, W.P. Obesity. Lancet 2005, 366, 1197-1209.

3. Vaisse, C.; Halaas, J.L.; Horvath, C.M.; Darnell, J.E., Jr.; Stoffel, M.; Friedman, J.M. Leptin activation of Stat3 in the hypothalamus of wild-type and ob/ob mice but not $\mathrm{db} / \mathrm{db}$ mice. Nat. Genet. 1996, 14, 95-97. 
4. Zhang, Y.; Proenca, R.; Maffei, M.; Barone, M.; Leopold, L.; Friedman, J.M. Positional cloning of the mouse obese gene and its human homologue. Nature 1994, 372, 425-432.

5. Loffreda, S.; Yang, S.Q.; Lin, H.Z.; Karp, C.L.; Brengman, M.L.; Wang, D.J.; Klein, A.S.; Bulkley, G.B.; Bao, C.; Noble, P.W.; et al. Leptin regulates proinflammatory immune responses. FASEB J. 1998, 12, 57-65.

6. Hotamisligil, G.S.; Arner, P.; Caro, J.F.; Atkinson, R.L.; Spiegelman, B.M. Increased adipose tissue expression of tumor necrosis factor-alpha in human obesity and insulin resistance. J. Clin. Investig. 1995, 95, 2409-2415.

7. Weisberg, S.P.; McCann, D.; Desai, M.; Rosenbaum, M.; Leibel, R.L.; Ferrante, A.W., Jr. Obesity is associated with macrophage accumulation in adipose tissue. J. Clin. Investig. 2003, 112, 1796-1808.

8. Lumeng, C.N.; DelProposto, J.B.; Westcott, D.J.; Saltiel, A.R. Phenotypic switching of adipose tissue macrophages with obesity is generated by spatiotemporal differences in macrophage subtypes. Diabetes 2008, 57, 3239-3246.

9. Zeyda, M.; Farmer, D.; Todoric, J.; Aszmann, O.; Speiser, M.; Gyori, G.; Zlabinger, G.J.; Stulnig, T.M. Human adipose tissue macrophages are of an anti-inflammatory phenotype but capable of excessive pro-inflammatory mediator production. Int. J. Obesity 2007, 31, 1420-1428.

10. Gordon, S. Alternative activation of macrophages. Nat. Rev. Immunol. 2003, 3, 23-35.

11. Kosteli, A.; Sugaru, E.; Haemmerle, G.; Martin, J.F.; Lei, J.; Zechner, R.; Ferrante, A.W., Jr. Weight loss and lipolysis promote a dynamic immune response in murine adipose tissue. J. Clin. Investig. 2010, 120, 3466-3479.

12. Jiao, P.; Chen, Q.; Shah, S.; Du, J.; Tao, B.; Tzameli, I.; Yan, W.; Xu, H. Obesity-related upregulation of monocyte chemotactic factors in adipocytes: Involvement of nuclear factor-kappaB and c-Jun NH2-terminal kinase pathways. Diabetes 2009, 58, 104-115.

13. Fujisaka, S.; Usui, I.; Ikutani, M.; Aminuddin, A.; Takikawa, A.; Tsuneyama, K.; Mahmood, A.; Goda, N.; Nagai, Y.; Takatsu, K.; et al. Adipose tissue hypoxia induces inflammatory M1 polarity of macrophages in an HIF-1 $\alpha$-dependent and Hif- $1 \alpha$-independent manner in obese mice. Diabetologia 2013, 56, 1403-1412.

14. Cancello, R.; Henegar, C.; Viguerie, N.; Taleb, S.; Poitou, C.; Rouault, C.; Coupaye, M.; Pelloux, V.; Hugol, D.; Bouillot, J.L.; et al. Reduction of macrophage infiltration and chemoattractant gene expression changes in white adipose tissue of morbidly obese subjects after surgery-induced weight loss. Diabetes 2005, 54, 2277-2286.

15. Taylor, C.T.; Kent, B.D.; Crinion, S.J.; McNicholas, W.T.; Ryan, S. Human adipocytes are highly sensitive to intermittent hypoxia induced NF-kappaB activity and subsequent inflammatory gene expression. Biochem. Biophys. Res. Commun. 2014, 447, 660-665.

16. Gao, Z.; Hwang, D.; Bataille, F.; Lefevre, M.; York, D.; Quon, M.J.; Ye, J. Serine phosphorylation of insulin receptor substrate 1 by inhibitor kappa B kinase complex. J. Biol. Chem. 2002, 277, 48115-48121.

17. Hirosumi, J.; Tuncman, G.; Chang, L.; Gorgun, C.Z.; Uysal, K.T.; Maeda, K.; Karin, M.; Hotamisligil, G.S. A central role for jnk in obesity and insulin resistance. Nature 2002, 420, 333-336. 
18. Arkan, M.C.; Hevener, A.L.; Greten, F.R.; Maeda, S.; Li, Z.W.; Long, J.M.; Wynshaw-Boris, A.; Poli, G.; Olefsky, J.; Karin, M. IKK-beta links inflammation to obesity-induced insulin resistance. Nat. Med. 2005, 11, 191-198.

19. Davis, J.E.; Gabler, N.K.; Walker-Daniels, J.; Spurlock, M.E. The c-Jun $N$-terminal kinase mediates the induction of oxidative stress and insulin resistance by palmitate and toll-like receptor 2 and 4 ligands in 3T3-L1 adipocytes. Horm. Metab.Res. 2009, 41, 523-530.

20. Lacasa, D.; Taleb, S.; Keophiphath, M.; Miranville, A.; Clement, K. Macrophage-secreted factors impair human adipogenesis: Involvement of proinflammatory state in preadipocytes. Endocrinology 2007, 148, 868-877.

21. Brown, M.S.; Goldstein, J.L. The srebp pathway: Regulation of cholesterol metabolism by proteolysis of a membrane-bound transcription factor. Cell 1997, 89, 331-340.

22. Mandrup, S.; Lane, M.D. Regulating adipogenesis. J. Biol. Chem. 1997, 272, 5367-5370.

23. Morrison, R.F.; Farmer, S.R. Hormonal signaling and transcriptional control of adipocyte differentiation. J. Nutr. 2000, 130, 3116S-3121S.

24. Rosen, E.D.; Walkey, C.J.; Puigserver, P.; Spiegelman, B.M. Transcriptional regulation of adipogenesis. Genes Dev. 2000, 14, 1293-1307.

25. Tamori, Y.; Masugi, J.; Nishino, N.; Kasuga, M. Role of peroxisome proliferator-activated receptor-gamma in maintenance of the characteristics of mature 3T3-l1 adipocytes. Diabetes 2002, 51, 2045-2055.

26. Fajas, L.; Fruchart, J.C.; Auwerx, J. Transcriptional control of adipogenesis. Curr. Opin. Cell Biol. 1998, 10, 165-173.

27. Wu, Z.; Rosen, E.D.; Brun, R.; Hauser, S.; Adelmant, G.; Troy, A.E.; McKeon, C.; Darlington, G.J.; Spiegelman, B.M. Cross-regulation of C/EBP alpha and PPAR gamma controls the transcriptional pathway of adipogenesis and insulin sensitivity. Mol. Cell 1999, 3, 151-158.

28. Spiegelman, B.M. PPAR-gamma: Adipogenic regulator and thiazolidinedione receptor. Diabetes 1998, 47, 507-514.

29. Fox, K.E.; Fankell, D.M.; Erickson, P.F.; Majka, S.M.; Crossno, J.T., Jr.; Klemm, D.J. Depletion of cAMP-response element-binding protein/ATF1 inhibits adipogenic conversion of 3T3-L1 cells ectopically expressing CCAAT/enhancer-binding protein (C/EBP) alpha, C/EBP beta, or PPAR gamma 2. J. Biol. Chem. 2006, 281, 40341-40353.

30. Siriwardhana, N.; Kalupahana, N.S.; Cekanova, M.; LeMieux, M.; Greer, B.; Moustaid-Moussa, N. Modulation of adipose tissue inflammation by bioactive food compounds. J. Nutr. Biochem. 2013, 24, 613-623.

31. Mosimann, A.L.; Wilhelm-Filho, D.; da Silva, E.L. Aqueous extract of Ilex paraguariensis attenuates the progression of atherosclerosis in cholesterol-fed rabbits. Biofactors 2006, 26, 59-70.

32. Bastos, D.H.M.; de Oliveira, D.M.; Matsumoto, R.L.T.; Carvalho, P.O.; Ribeiro, M.L. Yerba mate: Pharmacological properties, research and biotechnology. Med. Aromat. Plant Sci. Biotechnol. 2007, 1, 37-46.

33. Gugliucci, A. Antioxidant effects of Ilex paraguariensis: Induction of decreased oxidability of human ldl in vivo. Biochem. Biophys. Res. Commun. 1996, 224, 338-344. 
34. Gugliucci, A.; Menini, T. The botanical extracts of Achyrocline satureoides and Ilex paraguariensis prevent methylglyoxal-induced inhibition of plasminogen and antithrombin III. Life Sci. 2002, 72, 279-292.

35. Miranda, D.D.; Arcari, D.P.; Pedrazzoli, J., Jr.; Carvalho Pde, O.; Cerutti, S.M.; Bastos, D.H.; Ribeiro, M.L. Protective effects of mate tea (Ilex paraguariensis) on $\mathrm{H}_{2} \mathrm{O}_{2}$-induced DNA damage and DNA repair in mice. Mutagenesis 2008, 23, 261-265.

36. Boaventura, B.C.; di Pietro, P.F.; Stefanuto, A.; Klein, G.A.; de Morais, E.C.; de Andrade, F.; Wazlawik, E.; da Silva, E.L. Association of mate tea (Ilex paraguariensis) intake and dietary intervention and effects on oxidative stress biomarkers of dyslipidemic subjects. Nutrition 2012, 28, 657-664.

37. Fernandes, E.S.; de Oliveira Machado, M.; Becker, A.M.; de Andrade, F.; Maraschin, M.; da Silva, E.L. Yerba mate (Ilex paraguariensis) enhances the gene modulation and activity of paraoxonase-2: In vitro and in vivo studies. Nutrition 2012, 28, 1157-1164.

38. Bixby, M.; Spieler, L.; Menini, T.; Gugliucci, A. Ilex paraguariensis extracts are potent inhibitors of nitrosative stress: A comparative study with green tea and wines using a protein nitration model and mammalian cell cytotoxicity. Life Sci. 2005, 77, 345-358.

39. Paganini Stein, F.L.; Schmidt, B.; Furlong, E.B.; Souza-Soares, L.A.; Soares, M.C.; Vaz, M.R.; Muccillo Baisch, A.L. Vascular responses to extractable fractions of Ilex paraguariensis in rats fed standard and high-cholesterol diets. Biol. Res. Nurs. 2005, 7, 146-156.

40. Lunceford, N.; Gugliucci, A. Ilex paraguariensis extracts inhibit age formation more efficiently than green tea. Fitoterapia 2005, 76, 419-427.

41. Gugliucci, A.; Bastos, D.H.; Schulze, J.; Souza, M.F. Caffeic and chlorogenic acids in Ilex paraguariensis extracts are the main inhibitors of age generation by methylglyoxal in model proteins. Fitoterapia 2009, 80, 339-344.

42. Pereira, D.F.; Kappel, V.D.; Cazarolli, L.H.; Boligon, A.A.; Athayde, M.L.; Guesser, S.M.; da Silva, E.L.; Silva, F.R. Influence of the traditional Brazilian drink Ilex paraguariensis tea on glucose homeostasis. Phytomedicine 2012, 19, 868-877.

43. Hussein, G.M.; Matsuda, H.; Nakamura, S.; Akiyama, T.; Tamura, K.; Yoshikawa, M. Protective and ameliorative effects of mate (Ilex paraguariensis) on metabolic syndrome in tsod mice. Phytomedicine 2011, 19, 88-97.

44. Kang, Y.R.; Lee, H.Y.; Kim, J.H.; Moon, D.I.; Seo, M.Y.; Park, S.H.; Choi, K.H.; Kim, C.R.; Kim, S.H.; Oh, J.H.; et al. Anti-obesity and anti-diabetic effects of yerba mate (Ilex paraguariensis) in C57Bl/6J mice fed a high-fat diet. Lab. Anim. Res. 2012, 28, 23-29.

45. Arcari, D.P.; Bartchewsky, W., Jr.; dos Santos, T.W.; Oliveira, K.A.; DeOliveira, C.C.; Gotardo, E.M.; Pedrazzoli, J., Jr.; Gambero, A.; Ferraz, L.F.; Carvalho Pde, O.; et al. Anti-inflammatory effects of yerba mate extract (Ilex paraguariensis) ameliorate insulin resistance in mice with high fat diet-induced obesity. Mol. Cell. Endocrinol. 2011, 335, 110-115.

46. Pimentel, G.D.; Lira, F.S.; Rosa, J.C.; Caris, A.V.; Pinheiro, F.; Ribeiro, E.B.; Oyama, L.M.; Oller do Nascimento, C.M. Yerba mate extract (Ilex paraguariensis) attenuates both central and peripheral inflammatory effects of diet-induced obesity in rats. J. Nutr. Biochem. 2013, 24, 809-818. 
47. Carmo, L.S.; Rogero, M.M.; Cortez, M.; Yamada, M.; Jacob, P.S.; Bastos, D.H.; Borelli, P.; Ambrosio Fock, R. The effects of yerba mate (Ilex paraguariensis) consumption on IL-1, IL-6, TNF-alpha and IL-10 production by bone marrow cells in wistar rats fed a high-fat diet. Int. J. Vitam. Nutr. Res. 2013, 83, 26-35.

48. Borges, M.C.; Vinolo, M.A.; Nakajima, K.; de Castro, I.A.; Bastos, D.H.; Borelli, P.; Fock, R.A.; Tirapegui, J.; Curi, R.; Rogero, M.M. The effect of mate tea (Ilex paraguariensis) on metabolic and inflammatory parameters in high-fat diet-fed wistar rats. Int. J. Food Sci. Nutr. 2013, 64, 561-569.

49. Arcari, D.P.; Bartchewsky, W.; dos Santos, T.W.; Oliveira, K.A.; Funck, A.; Pedrazzoli, J.; de Souza, M.F.F.; Saad, M.J.; Bastos, D.H.M.; Gambero, A.; et al. Antiobesity effects of yerba mate extract (Ilex paraguariensis) in high-fat diet-induced obese mice. Obesity 2009, 17, 2127-2133.

50. Filip, R.; Sebastian, T.; Ferraro, G.; Anesini, C. Effect of Ilex extracts and isolated compounds on peroxidase secretion of rat submandibulary glands. Food Chem. Toxicol. 2007, 45, 649-655.

51. Ramirez-Mares, M.V.; Chandra, S.; de Mejia, E.G. In vitro chemopreventive activity of Camellia sinensis, Ilex paraguariensis and Ardisia compressa tea extracts and selected polyphenols. Mutat. Res. 2004, 554, 53-65.

52. Puangpraphant, S.; Berhow, M.A.; Vermillion, K.; Potts, G.; Gonzalez de Mejia, E. Dicaffeoylquinic acids in yerba mate (Ilex paraguariensis st. Hilaire) inhibit NF-kappaB nucleus translocation in macrophages and induce apoptosis by activating caspases- 8 and -3 in human colon cancer cells. Mol. Nutr. Food Res. 2011, 55, 1509-1522.

53. Puangpraphant, S.; Dia, V.P.; de Mejia, E.G.; Garcia, G.; Berhow, M.A.; Wallig, M.A. Yerba mate tea and mate saponins prevented azoxymethane-induced inflammation of rat colon through suppression of NF-kappaB p65ser(311) signaling via IkappaB-alpha and GSK-3beta reduced phosphorylation. Biofactors 2013, 39, 430-440.

54. Martinet, A.; Hostettmann, K.; Schutz, Y. Thermogenic effects of commercially available plant preparations aimed at treating human obesity. Phytomedicine 1999, 6, 231-238.

55. Oliveira, D.M.; Freitas, H.S.; Souza, M.F.; Arcari, D.P.; Ribeiro, M.L.; Carvalho, P.O.; Bastos, D.H. Yerba mate (Ilex paraguariensis) aqueous extract decreases intestinal SGLT1 gene expression but does not affect other biochemical parameters in alloxan-diabetic wistar rats. J. Agric. Food Chem. 2008, 56, 10527-10532.

56. Lima Nda, S.; Franco, J.G.; Peixoto-Silva, N.; Maia, L.A.; Kaezer, A.; Felzenszwalb, I.; de Oliveira, E.; de Moura, E.G.; Lisboa, P.C. Ilex paraguariensis (yerba mate) improves endocrine and metabolic disorders in obese rats primed by early weaning. Eur. J. Nutr. 2014, 53, 73-82.

57. Arcari, D.P.; Santos, J.C.; Gambero, A.; Ferraz, L.F.; Ribeiro, M.L. Modulatory effects of yerba mate (Ilex paraguariensis) on the PI3K-AKT signaling pathway. Mol. Nutr. Food Res. 2013, 57, 1882-1885.

58. Pang, J.; Choi, Y.; Park, T. Ilex paraguariensis extract ameliorates obesity induced by high-fat diet: Potential role of ampk in the visceral adipose tissue. Arch. Biochem. Biophys. 2008, 476, 178-185.

59. Arcari, D.P.; Santos, J.C.; Gambero, A.; Ribeiro, M.L. The in vitro and in vivo effects of yerba mate (Ilex paraguariensis) extract on adipogenesis. Food Chem. 2013, 141, 809-815.

60. Gosmann, G.; Barlette, A.G.; Dhamer, T.; Arcari, D.P.; Santos, J.C.; de Camargo, E.R.; Acedo, S.; Gambero, A.; Gnoatto, S.C.; Ribeiro, M.L. Phenolic compounds from mate (Ilex paraguariensis) inhibit adipogenesis in 3T3-L1 preadipocytes. Plant Foods Hum. Nutr. 2012, 67, 156-161. 
61. Hussein, G.M.; Matsuda, H.; Nakamura, S.; Hamao, M.; Akiyama, T.; Tamura, K.; Yoshikawa, M. Mate tea (Ilex paraguariensis) promotes satiety and body weight lowering in mice: Involvement of glucagon-like peptide-1. Biol. Pharm. Bull. 2011, 34, 1849-1855.

62. Resende, P.E.; Verza, S.G.; Kaiser, S.; Gomes, L.F.; Kucharski, L.C.; Ortega, G.G. The activity of mate saponins (Ilex paraguariensis) in intra-abdominal and epididymal fat, and glucose oxidation in male wistar rats. J. Ethnopharmacol. 2012, 144, 735-740.

63. Martins, F.; Noso, T.M.; Porto, V.B.; Curiel, A.; Gambero, A.; Bastos, D.H.; Ribeiro, M.L.; Carvalho Pde, O. Mate tea inhibits in vitro pancreatic lipase activity and has hypolipidemic effect on high-fat diet-induced obese mice. Obesity 2010, 18, 42-47.

64. Bracesco, N.; Sanchez, A.G.; Contreras, V.; Menini, T.; Gugliucci, A. Recent advances on Ilex paraguariensis research: Minireview. J. Ethnopharmacol. 2011, 136, 378-384.

65. Gugliucci, A.; Stahl, A.J. Low density lipoprotein oxidation is inhibited by extracts of Ilex paraguariensis. Biochem. Mol. Biol. Int. 1995, 35, 47-56.

66. Andersen, T.; Fogh, J. Weight loss and delayed gastric emptying following a south American herbal preparation in overweight patients. J. Hum. Nutr. Diet. 2001, 14, 243-250.

67. Harrold, J.A.; Hughes, G.M.; O’Shiel, K.; Quinn, E.; Boyland, E.J.; Williams, N.J.; Halford, J.C. Acute effects of a herb extract formulation and inulin fibre on appetite, energy intake and food choice. Appetite 2013, 62, 84-90.

68. De Morais, E.C.; Stefanuto, A.; Klein, G.A.; Boaventura, B.C.; de Andrade, F.; Wazlawik, E.; di Pietro, P.F.; Maraschin, M.; da Silva, E.L. Consumption of yerba mate (Ilex paraguariensis) improves serum lipid parameters in healthy dyslipidemic subjects and provides an additional LDL-cholesterol reduction in individuals on statin therapy. J. Agric. Food Chem. 2009, 57, 8316-8324.

69. Gao, H.; Liu, Z.; Qu, X.; Zhao, Y. Effects of yerba mate tea (Ilex paraguariensis) on vascular endothelial function and liver lipoprotein receptor gene expression in hyperlipidemic rats. Fitoterapia 2013, 84, 264-272.

70. Hemmerle, H.; Burger, H.J.; Below, P.; Schubert, G.; Rippel, R.; Schindler, P.W.; Paulus, E.; Herling, A.W. Chlorogenic acid and synthetic chlorogenic acid derivatives: Novel inhibitors of hepatic glucose-6-phosphate translocase. J. Med. Chem. 1997, 40, 137-145.

71. Nardini, M.; D’Aquino, M.; Tomassi, G.; Gentili, V.; di Felice, M.; Scaccini, C. Inhibition of human low-density lipoprotein oxidation by caffeic acid and other hydroxycinnamic acid derivatives. Free Radic Biol. Med. 1995, 19, 541-552.

72. Han, L.K.; Zheng, Y.N.; Xu, B.J.; Okuda, H.; Kimura, Y. Saponins from platycodi radix ameliorate high fat diet-induced obesity in mice. J. Nutr. 2002, 132, 2241-2245.

73. Tseng, Y.H.; Butte, A.J.; Kokkotou, E.; Yechoor, V.K.; Taniguchi, C.M.; Kriauciunas, K.M.; Cypess, A.M.; Niinobe, M.; Yoshikawa, K.; Patti, M.E.; et al. Prediction of preadipocyte differentiation by gene expression reveals role of insulin receptor substrates and necdin. Nat. Cell Biol. 2005, 7, 601-611.

74. Tong, Q.; Tsai, J.; Tan, G.; Dalgin, G.; Hotamisligil, G.S. Interaction between gata and the C/EBP family of transcription factors is critical in gata-mediated suppression of adipocyte differentiation. Mol. Cell Biol. 2005, 25, 706-715. 
75. Banerjee, S.S.; Feinberg, M.W.; Watanabe, M.; Gray, S.; Haspel, R.L.; Denkinger, D.J.; Kawahara, R.; Hauner, H.; Jain, M.K. The kruppel-like factor KLF2 inhibits peroxisome proliferator-activated receptor-gamma expression and adipogenesis. J. Biol. Chem. 2003, 278, 2581-2584.

76. Hotamisligil, G.S. Inflammation and metabolic disorders. Nature 2006, 444, 860-867.

77. Shimomura, I.; Hammer, R.E.; Ikemoto, S.; Brown, M.S.; Goldstein, J.L. Leptin reverses insulin resistance and diabetes mellitus in mice with congenital lipodystrophy. Nature 1999, 401, 73-76.

78. Farese, R.V.; Sajan, M.P.; Standaert, M.L. Insulin-sensitive protein kinases (atypical protein kinase $\mathrm{C}$ and protein kinase B/AKT): Actions and defects in obesity and type II diabetes. Exp. Biol. Med. (Maywood) 2005, 230, 593-605.

(C) 2015 by the authors; licensee MDPI, Basel, Switzerland. This article is an open access article distributed under the terms and conditions of the Creative Commons Attribution license (http://creativecommons.org/licenses/by/4.0/). 